\title{
Changes in physical features of Glacier No. 1 of the Tianshan Mountains in response to climate change
}

\author{
LI Xiang Ying ${ }^{1,2 *}$, DING YongJian ${ }^{2}$, YE BaiSheng ${ }^{2} \&$ HAN TianDing ${ }^{2}$ \\ ${ }^{1}$ Institute of Climate System, Chinese Academy of Meteorological Sciences, Beijing 100081, China; \\ ${ }^{2}$ State Key Laboratory of Cryospheric Science, Cold and Arid Regions Environmental and Engineering Research Institute, Chinese Academy of \\ Sciences, Lanzhou 730000, China
}

Received February 18, 2011; accepted June 3, 2011

\begin{abstract}
This study analyzes the changes in glacier zones and snow composition of Glacier No. 1 in the Tianshan Mountains of China since 1961, and their possible relations with climate. It is found that precipitation dominated the snow composition and that air temperature and precipitation controlled the distribution of glacier zones, but interannual change in precipitation had a relatively large effect on glacier zones and snow composition during 1963-1981 ( $\left.\mathrm{P}_{0}\right)$ and 1963-1989 (P1 $)$. However, during 1982-2007 $\left(\mathrm{P} 2_{0}\right)$ and $1990-2007\left(\mathrm{P} 2_{1}\right)$, the air temperature rise $\left(0.57^{\circ} \mathrm{C} / 10\right.$ a for $\mathrm{P} 2_{0}, 0.76^{\circ} \mathrm{C} / 10$ a for $\left.\mathrm{P} 2_{1}\right)$ was more influential than the precipitation increase $\left(51.3 \mathrm{~mm} / 10\right.$ a for $\left.\mathrm{P} 2_{0}\right)$, and air temperature was principally responsible for the evolution of glacier zones and snow composition most probably resulting from recent climate warming.
\end{abstract}

climate change, mass balance, glacier zones, snow composition, Glacier No. 1 of the Tianshan Mountains

Citation: $\quad$ Li X Y, Ding Y J, Ye B S, et al. Changes in physical features of Glacier No. 1 of the Tianshan Mountains in response to climate change. Chinese Sci Bull, 2011, 56: 2820-2827, doi: 10.1007/s11434-011-4621-x

Glaciers are widely recognized as one of the most visible and excellent indicators of climate change [1-3] since the glacier mass balance can be used to infer climatic information from glacier accumulation and ablation (i.e. the glacier mass balance) [4]. Glacier zones characterized by different ice formation processes (i.e. the water-heat condition) are distinct parts of the surface layer of glaciers or ice sheets, and their distribution is closely related to patterns of the glacier mass balance [5-8]. Moreover, boundaries between glacier zones provide information on the firn line that documents the current spatial extent of the ablation area, the wet-snow line that coincides with the position of the $0^{\circ} \mathrm{C}$ isotherm, and the dry-snow line that indicates singular extreme melt events. In particular, the altitude of the firn line at the end of an ablation season, often referred to as the equilibrium line altitude (ELA), is a key parameter of the glacier mass balance [9-12]. Additionally, snow cover in

*Corresponding author (email: shaanxilxy@163.com) the accumulation area of glaciers consists of numerous layers (e.g. dust, ice, and firn layers) formed by snowfall, wind erosion, atmospheric deposition and metamorphic processes (e.g. densification, melting, and freezing) [13]. The transfer of mass and energy through snow cover strongly depends on the numbers and properties of these layers preserved in the snow cover because most fluxes are perpendicular to the snow surface [14,15]. Consequently, glacier ablation is closely associated with surface-snow properties, such as the snow grain size, and thereby depends principally on atmospheric air temperature [16]. The distribution of glacier zones and the composition of snow cover on glaciers fluctuate year by year according to weather conditions [7], but on relatively long timescales (e.g. ten years or longer), the zone distribution and snow composition are well sensitive to the glacier mass balance and hence climate change (e.g. atmospheric air temperature and precipitation amount) particularly under global warming. The glacier zones and snow composition play a greatly important role in the climate 
responses of glaciers particularly in basins, where available glacier data such as data on the glacier mass balance, glacier volume, glacier area, meteorology and hydrology are scarce probably because of the difficulties involved in and the oversights of field examinations of glacier zones and snow composition. Using limited published data on the glacier zones and snow composition of Glacier No. 1 in the eastern Tianshan Mountains, this paper examines glacier changes during different periods to analyze possible relations with air temperature and precipitation and eventually to quantify the glacier's response to climate change. This work will draw more attention from climatologists to glacier responses to climate change under global warming.

\section{Study area}

Glacier No. $1\left(43^{\circ} 06^{\prime} \mathrm{N}, 86^{\circ} 49^{\prime} \mathrm{E}\right)$ at the head of the Urumqi River in the eastern Tianshan Mountains of central Asia is surrounded by vast deserts - the Gobi desert to the east, the Taklimakan desert in the Tarim basin to the south, the Peski Muyunkum and Peski Sary-Ishikotrau deserts to the west, and the Gurbantunggut desert in the Junggar basin to the north [17]. The mountain environment in this region includes a forest zone from 1500 to $2900 \mathrm{~m}$ a.s.l., alpine meadow above $2900 \mathrm{~m}$ a.s.l., and bare rock, glacial deposits and permafrost above $3000 \mathrm{~m}$ a.s.1. [18]. With there being a typical continental climate, a westerly jet prevails across these high mountains. Near the surface, local valley winds prevail from March through September [19,20], during which time the dominant wind directions are from the northeast and east-northeast [21].

Glacier No. 1 is a northwest-facing valley glacier comprising an east branch with elevation between 3740 and $4220 \mathrm{~m}$ a.s.l. and a west branch with elevation between 3740 and $4486 \mathrm{~m}$ a.s.l., and the glacier has a total area of about $1.68 \mathrm{~km}^{2}$ (in 2006) (Figure 1). The two branches separated into two independent glaciers in 1994 owing to persistent glacier shrinkage under global warming [22]. The ELA averaged approximately $4058 \mathrm{~m}$ a.s.l. from 1959 to 2006 [21,23], and the mean annual precipitation and air temperature are $456.8 \mathrm{~mm}$ and $-5.08^{\circ} \mathrm{C}$ respectively at the catchment. The Daxigou Meteorological Station (belonging to the China Meteorological Administration) is located at $3539 \mathrm{~m}$ a.s.l. and about $3 \mathrm{~km}$ downstream of Glacier No. 1 (Figure 1). A hydrological station was established $200 \mathrm{~m}$ downstream of the terminus of Glacier No. 1 (3689 m a.s.1.), where the discharge is solely supplied by the glacier (Figure 1). In the catchment, routine observations include those of the glacier mass balance [24], glacier length and area [25], and meteorology and hydrology [22]. In addition, the snow composition has been investigated in the accumulation area (above the ELA) on both branches at altitudes of 4068 to $4400 \mathrm{~m}$ a.s.l. since 1961, including observations of snow depth, snow density, dust layers, ice layers, superimposed

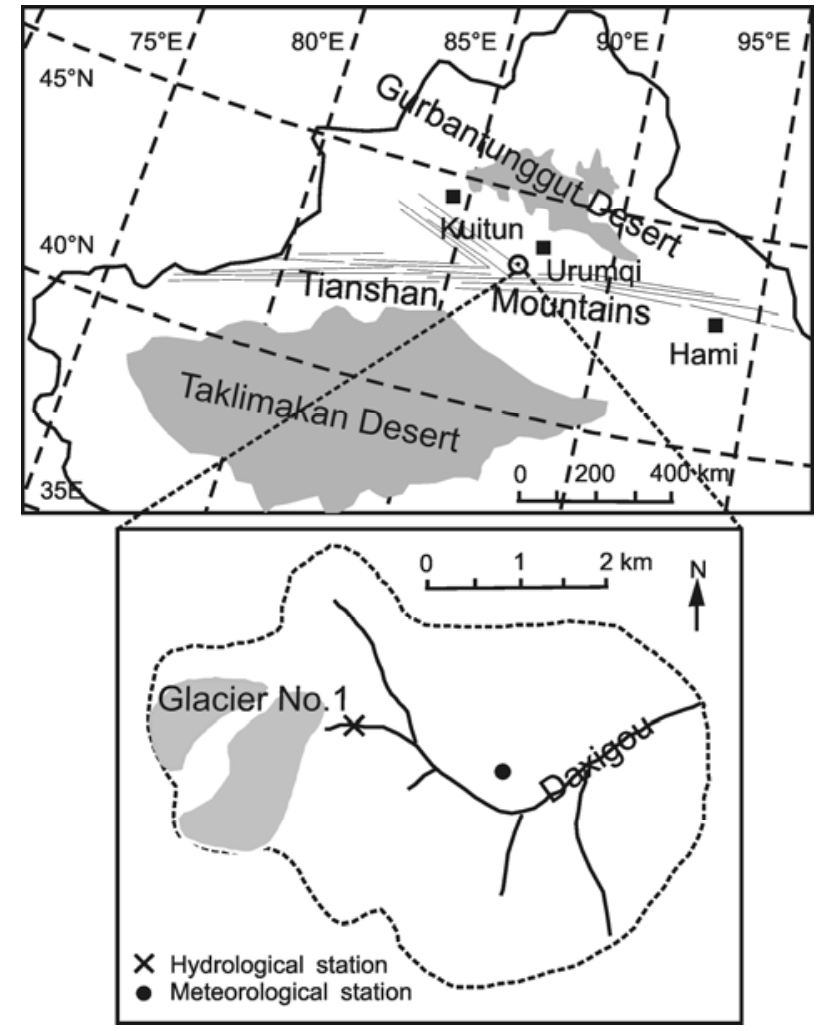

Figure 1 Map showing Glacier No.1, the Daxigou Meteorological Station and a hydrological station near the terminal of Glacier No.1 at the head of the Urumqi River.

ice, and grain size and type [26-28], and the distribution of glacier zones has been studied [26,28-30].

\section{Data and method}

This study takes data of snow profiles for the periods (May to September) 1961-1962 (26 profiles with intervals of 7 to 30 d) [26,31], 1980-1981 (31 profiles with intervals of 8 to 20 d) [27] and 2003-2004 (40 profiles with intervals of 7 d) [32] and data of glacier zones for the years 1962 [26], 1989 [29] and 2004 [28,30]. Data of the glacier mass balance are taken from the Annual Report of Tianshan Glaciological Station, in which data for 1967-1979 are the reconstructed mass balance [22]. Data of summer air temperature and annual precipitation have been collected continuously since 1959 by the Daxigou Meteorological Station. Discharge data have been collected continuously from the hydrological station at the terminal of Glacier No. 1 during the ablation period since 1980. For these data, the snow composition is classified on the basis of the diameter of the snow grain into fine-grain firn $(<1 \mathrm{~mm})$, medium-grain firn (1-3 mm) and coarse-grain firn $(>3 \mathrm{~mm})$. The classification is relatively concise, involves easy identification and quantification, and is more accurate [26-28] relative to the International Classification for Seasonal Snow on the Ground [33]. The parti- 
tioning of glacier zones is based on the classification of Paterson (1994) (i.e.dry-snow zone, percolation zone, wet-snow zone, superimposed-ice zone and ablation area from the summit to terminal of a glacier). The boundaries between glacier zones are judged according to the location of the equilibrium line, the boundary between firn and ice on the glacier surface at the end of the melt season, the boundary where all snow deposited since the end of the previous summer warmed to the melting temperature by the end of the current summer, and field observations of superimposed ice and percolation ice at the bottom of the snow cover [26,28-30].

Using a limited and discontinuous but valuable database for the snow composition and glacier zones of Glacier No. 1 since 1961, we compare the glacier zones in 1962, 1989 and 2004 and the snow composition during 1961-1962, 19801981 and 2003-2004 to examine their temporal variations, carry out trend analyses employing linear regression for long-term meteorological, hydrological and glacier data to analyze possible relations among summer air temperature, annual precipitation, annual mass balance and annual discharge, and quantify the effects of climate change (in terms of air temperature and precipitation) on the distribution of glacier zones during 1963-1989 and 1990-2004 and snow composition during 1963-1981 and 1982-2004 (relative to the glacier mass balance) for Glacier No. 1 under global warming.

\section{Results and discussion}

\subsection{Changes in glacier zones and snow composition}

Changes in glacier zones, such as changes in area and position (boundary elevation), are directly associated with glacier accumulation and ablation, and the boundaries between glacier zones provide useful information on the glacier mass balance [7-10]. Figure 2 shows the distribution of glacier zones and the snow composition for Glacier No. 1 since 1961. In 1962, from the glacier terminus to summit, the glacier zones were an ablation area (AA), superimposed-ice zone (SIZ), wet-snow zone (WSZ) and percolation zone (PZ) [26] (Figure 2a). The SIZ was in several distinct parts, and small patches appeared at the head of the west branch and in an area near a mountain ridge on the east branch most possibly as a result of the valley terrain. The maximum thickness of superimposed ice was 45 and $265 \mathrm{~cm}$ in the AA (seasonal superimposed ice) and SIZ respectively [26]. By 1989, the glacier zones were the AA, SIZ and WSZ, and the maximum thickness of superimposed ice was 23 and $38 \mathrm{~cm}$ in the AA and SIZ respectively [29]. During 1962-1989, the

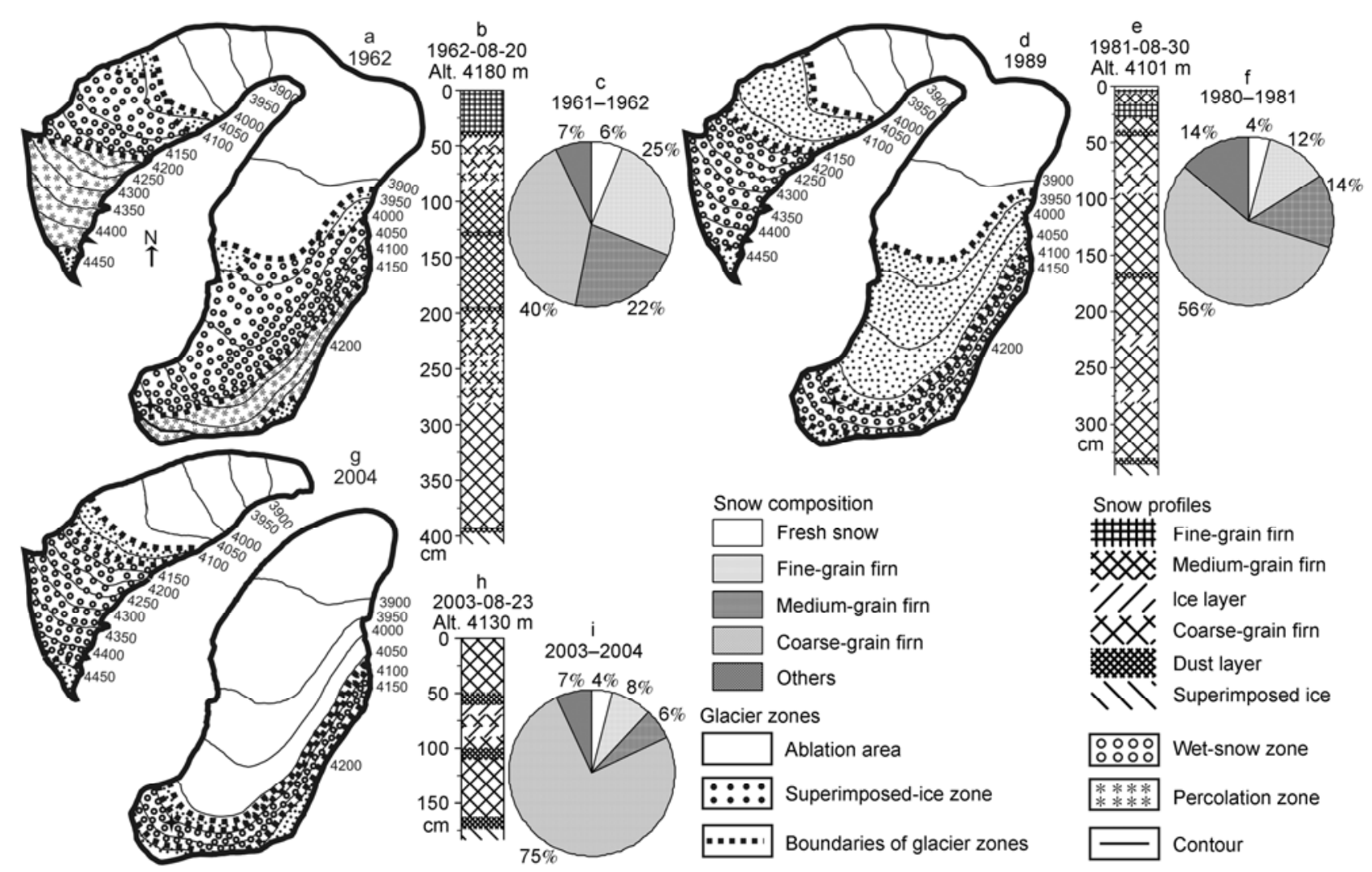

Figure 2 Glacier zones in 1962 (a) [26], 1989 (d) [29] and 2004 (g) [28,30] and representative snow profiles and snow composition during 1961-1962 (b,c) [26,31], 1980-1981 [27] (e,f) and 2003-2004 (h,i) [32]. The black crisscross at the summit of the east branch in a, $\mathrm{d}$ and g indicate the locations of the representative snow profiles. The "fresh snow" and "others" in snow compositions indicate "fresh snowfall" and "composite layers" (e.g. ice layers and dust layers) respectively. 
SIZ obviously enlarged and appeared above the WSZ in regions adjacent to the summit of the east branch, the WSZ diminished particularly on the east branch and the boundaries between the SIZ and WSZ moved upward strikingly on both branches, and the PZ disappeared and was replaced by the WSZ (Figure 2a, d). Additionally, the superimposed ice decreased by 22 and $227 \mathrm{~cm}$ in the AA and SIZ respectively. In 2004, the glacier zones were still the AA, SIZ and WSZ [28,30]. During 1989-2004, the AA obviously enlarged, the SIZ diminished particularly on the east branch, and part of the SIZ disappeared and was replaced by the AA on the summit of the east branch (Figure $2 \mathrm{~d}, \mathrm{~g}$ ) as confirmed by a small meltwater pool that formed at the upper end of the east branch [34]. Additionally, the boundaries between the AA and SIZ moved upward $141 \mathrm{~m}$ on the east branch and $53 \mathrm{~m}$ on the west branch, and the boundaries between the SIZ and WSZ moved upward 23 and $6 \mathrm{~m}$ for east and west branches respectively. These results suggest that the quantity of meltwater and the percolation of meltwater in snow cover increased, and the time required to transform snow into ice decreased particularly in 2004 relative to times in 1962 and 1989 probably as a result of a rapid increase in heat input into the glacier interior and potential climate warming.

The weather and solar radiation control the snow stratigraphic characteristics, and seasonal boundaries within the annual strata correspond to times when air temperature gradients are steepest and when layers of sublimation crystals (depth hoar) are most likely to form within the snow cover [35]. The snow composition of Glacier No. 1 shows that the time required to transform snow into ice decreased, and the volume of meltwater in the snow cover and the snow density increased significantly (Figure 2b,c,e,f,h,i). For instance, an average of 4.9 dust layers were found in the snow cover during 1961-1962 (Table 1), suggesting that accumulation of the glacier mass during those 5 years remained above the ice $[21,31,36]$. Nevertheless, by 1980-1981 and 2003-2004, the average numbers of dust layers above the ice decreased to 4.2 and 2.9 respectively (Table 1 ). The decrease in the number of annual layers identified as dust layers indicates that the time required to transform snow into ice has been increasingly decreasing. Additionally, the snow cover contained eight ice layers in 1961-1962 but only 3.3 and 2.5 in 1980-1981 and 2003-2004 respectively (Table 1), as a result of an increase in meltwater content that destroyed ice layers [31]. Corresponding to these changes, the snow depth de- creased by $57 \mathrm{~cm}$ w.e. and snow density increased by 130 $\mathrm{kg} \mathrm{m}^{-3}$ between 1961-1962 and 2003-2004 (Table 1). Hereinto, the snow depth decreased by $24 \mathrm{~cm}$ w.e. and the snow density increased by $50 \mathrm{~kg} \mathrm{~m}^{-3}$ between 1961-1962 and 1980-1981, and the snow depth decreased by $33 \mathrm{~cm}$ w.e. and the snow density increased by $80 \mathrm{~kg} \mathrm{~m}^{-3}$ between 1980 1981 and 2003-2004. Additionally, fine-grain, mediumgrain and coarse-grain firn layers dominated the snow cover, and the proportion of fresh snow, fine-grain, medium-grain and coarse-grain firn layers and other layers (e.g., ice layers and dust layers) accounted for 6\%, 25\%, 22\%, 40\% and 7\% of the snow stratigraphy respectively in 1961-1962 (Figure 2b,c). By 1980-1981, the proportion of the coarse-grain firn layer increased from $40 \%$ to $56 \%$, but the proportion of fine-grain and medium-grain firn layers decreased from $25 \%$ to $12 \%$ and from $22 \%$ to $14 \%$ respectively (Figure 2e, f). By 2003-2004, the proportion of the coarse-grain firn layer increased to $75 \%$ and the proportion of the fine-grain and medium-grain firn layers decreased to $8 \%$ and $6 \%$ respectively (Figure 2h,i). Snow profiles became obviously less complex, boundaries among snow layers became less distinguishable, ice layers almost disappeared and the coarsegrain firn became the dominant firn type, suggesting a rapid increase in meltwater content in the snow cover and also an increase in heat input into the snow cover probably as a result of potential climate warming.

\subsection{Changes in climate}

Against the background of global warming, the climate of the head region of the Urumqi River has changed, particularly since 1997, with the most important indicators being summer air temperature and annual precipitation [22]. Figure 3 shows variations in summer air temperature, annual precipitation, annual mass balance, cumulative mass balance and annual discharge since 1959. During 1963-1981 $\left(\mathrm{P}_{0}\right)$ and 1963-1989 $\left(\mathrm{P}_{1}\right)$, air temperature and precipitation fluctuated but their trends were not significant (Figure $3 a, b)$. The glacier mass balance did not have an apparent trend during $\mathrm{P} 1_{0}$ but had a decreasing trend $(P=0.07)$ over $\mathrm{P} 1_{1}$ relating to a fluctuating discharge during 1980-1989 (Figure 3e), especially during 1978-1982 and 1984-1988; there was a continuous negative mass balance for 5 years twice since observations of the mass balance began, and the three years having the most negative mass balance (less than $-610 \mathrm{~mm}$ ) were all in the period 1984-1988 (Figure 3c).

Table 1 Average snow depth, snow density and numbers of ice layers and dust layers in snow cover on Glacier No. 1 during 1961-1962, 1980-1981 and 2003-2004

\begin{tabular}{cccccc}
\hline Periods & Numbers of profiles & Snow depth (cm w.e.) & Numbers of ice layers & Numbers of dust layers & Snow density $\left(\mathrm{kg} \mathrm{m}^{-3}\right)$ \\
\hline $1961-1962[26]$ & 26 & 139 & 8 & 4.9 & 540 \\
$1980-1981[27]$ & 31 & 115 & 3.3 & 4.2 & 590 \\
$2003-2004[28]$ & 40 & 82 & 2.5 & 2.9 & 670 \\
\hline
\end{tabular}




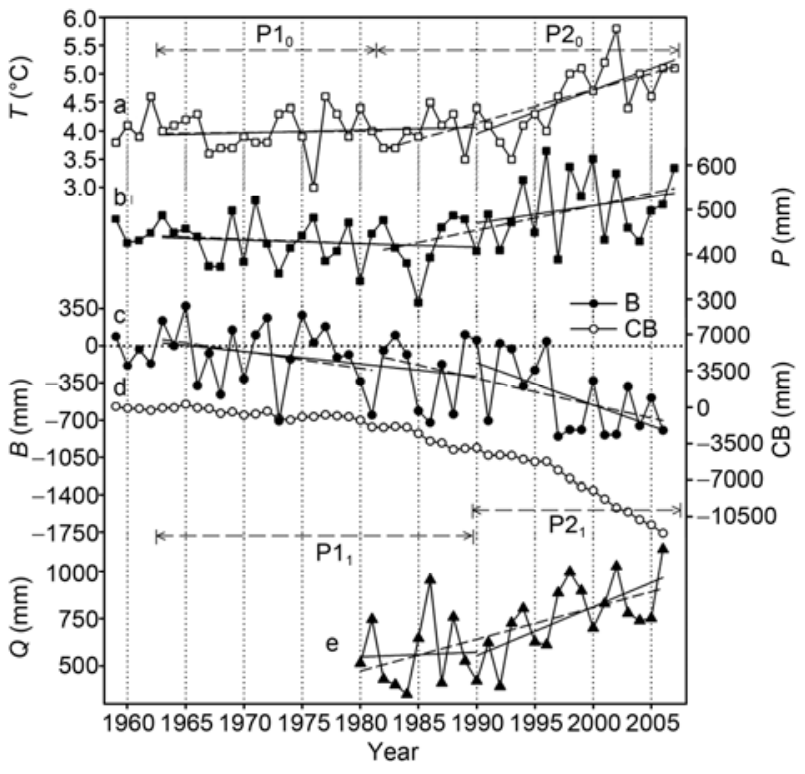

Figure 3 a, Summer air temperature $(T)$; b, annual precipitation $(P)$; c, annual mass balance $(B)$; d, cumulative mass balance $(C B)$ relative to 1959 ; $\mathrm{e}$, annual discharge $(Q)$ during $1959-2007 . \mathrm{P} 1_{0}$ and $\mathrm{P} 2_{0}$ indicate the periods 1963-1981 and 1982-2007 respectively relative to periods of snow composition, and $\mathrm{P} 1_{1}$ and $\mathrm{P} 2_{1}$ indicate periods 1963-1989 and 1990-2007 respectively relative to periods of glacier zones. The horizontal dashed lines indicate zero mass balances, and the inclined dashed lines and solid lines indicate linear trends during different periods.

Meanwhile, the cumulative mass balance reached $-1907.3 \mathrm{~mm}$ (in 1981) and $-3982.6 \mathrm{~mm}$ (in 1989), equivalent to glacier thinning of 2.14 and $4.47 \mathrm{~m}(3.9 \%$ and $8.1 \%$ of average glacier thickness in the early 1980s [37]), respectively (Figure 3d). This suggests that the intra-seasonal fluctuation in air temperature together with the intra-annual fluctuation in precipitation is correlated with a decrease in mass balance and fluctuation in discharge during $\mathrm{P} 1_{0}$ and $\mathrm{P} 1_{1}$. Additionally, air temperature in 1989 and $1980-1981$ was $1.1^{\circ} \mathrm{C}$ and $0.1^{\circ} \mathrm{C}$ less than that in 1962 and 1961-1962 respectively, and precipitation was $30.8 \mathrm{~mm}$ greater and $92.3 \mathrm{~mm}$ less respectively; however, the mass balance increased by 273.1 $\mathrm{mm}$ and decreased by $393.5 \mathrm{~mm}$ respectively, further suggesting that interannual fluctuation of the air temperature and precipitation are responsible for changes in the mass balance during $\mathrm{P} 1_{0}$ and $\mathrm{P} 1_{1}$.

During 1982-2007 (P2 $2_{0}$ and 1990-2007 (P2 $)$, however, the temperature increased sharply $\left(0.57^{\circ} \mathrm{C} / 10\right.$ a for $\mathrm{P} 2_{0}, P<$ $0.01 ; 0.76^{\circ} \mathrm{C} / 10$ a for $\left.\mathrm{P} 2, P<0.01\right)$, particularly after 1997 (Figure 3a). Precipitation increased abruptly over $\mathrm{P} 2_{0}(51.3$ $\mathrm{mm} / 10$ a, $P=0.02$ ) and had an unapparent varying trend during $\mathrm{P} 2{ }_{1}$ (Figure $3 \mathrm{~b}$ ). As a result, the glacier mass balance decreased rapidly in the past 26 years $(-248.02 \mathrm{~mm} / 10$ a for $\left.\mathrm{P} 2_{0}, P=0.01\right)$, but it has an apparent trend in the past 18 years $\left(P 2_{1}\right)$; in the most recent 10 years (1997-2006), the seven years having the most negative mass balance (less than $-750 \mathrm{~mm}$ ) are all after 1996 . Moreover, the cumulative mass balance reached $-12064 \mathrm{~mm}$ in 2006 , equivalent to glacier thinning of $13.6 \mathrm{~m}$ ( $25 \%$ of the average glacier thickness in the early 1980s [37]), which is consistent with the rapid increases in discharge $\left(197.2 \mathrm{~mm} / 10\right.$ a for $\mathrm{P} 2_{0}, P<$ $0.01 ; 257.5 \mathrm{~mm} / 10$ a for $\mathrm{P} 2{ }_{1}, P<0.01$ ) (Figure $3 \mathrm{e}$ ). These results indicate that increases in air temperature and precipitation most likely led to decreases in mass balance and increases in discharge during $\mathrm{P} 2_{0}$ and $\mathrm{P} 2_{1}$. In addition, there have been two positive mass balances, in 1992 (23 mm) and 1996 (42 mm), since the beginning of the 1990s (Figure 3c), which can be attributed to decreases in air temperature in both 1992 and 1996 and abrupt increases in precipitation in 1996 (632 mm, the greatest since 1959) (Figure 3a, b). Moreover, air temperature in 2004 and 2003-2004 was $1.5^{\circ} \mathrm{C}$ and $0.5^{\circ} \mathrm{C}$ higher than that in 1989 and $1980-1981$ respectively, and precipitation decreased by $49.5 \mathrm{~mm}$ and increased by $102.5 \mathrm{~mm}$ respectively, corresponding to decreases in mass balance of 860.6 and $75.6 \mathrm{~mm}$. This suggests that interannual fluctuations in air temperature and precipitation are also responsible for changes in the mass balance during $\mathrm{P} 2_{0}$ and $\mathrm{P} 2_{1}$.

\subsection{Correlation of changes in glacier zones, snow composition and climate}

The variation in glacier mass can be used to assess climate change [38], and studies on the relations between climate and the glacier mass balance $[39,40]$ are extraordinarily useful for understanding physical interactions between climate and glaciers on regional to global scales [38]. The glacier mass balance is affected mainly by variations in precipitation, melting and sublimation [41], and it is closely related to air temperature and physical characteristics of the material near the surface, which differ greatly among different glacier zones and snow compositions [7]. Moreover, the boundaries between the glacier zones indicate the glacier mass balance and climate variability $[5,9,10]$. Additionally, air temperature and precipitation as important indicators of climate change [2] affect the glacier mass balance; specifically, a precipitation increase enhances glacier accumulation (positive mass balance) and an air temperature rise enhances glacier ablation (negative mass balance) [22].

To quantify the effect of climate change on glacier zones and snow composition, we examine the relationships between summer air temperature and annual precipitation and the annual mass balance and annual discharge. During $\mathrm{P} 1_{0}$, the relation between air temperature and mass balance is not significant (statistically at 49\%) (Figure 4a), but precipitation is positively correlated with mass balance (statistically at $98 \%$ ) (Figure 4b), indicating that precipitation dominates the evolution of the snow composition, and the effect of precipitation on snow composition is obviously more significant than the effect of air temperature during $\mathrm{P} 1_{0}$, as confirmed by the relations between precipitation $\left(R^{2}=0.27\right.$, $P=0.02)$ and air temperature $\left(R^{2}=0.03, P=0.51\right)$ and the mass balance (Figure $4 \mathrm{a}, \mathrm{b}$ ). During $\mathrm{P} 1_{1}$, air temperature is 

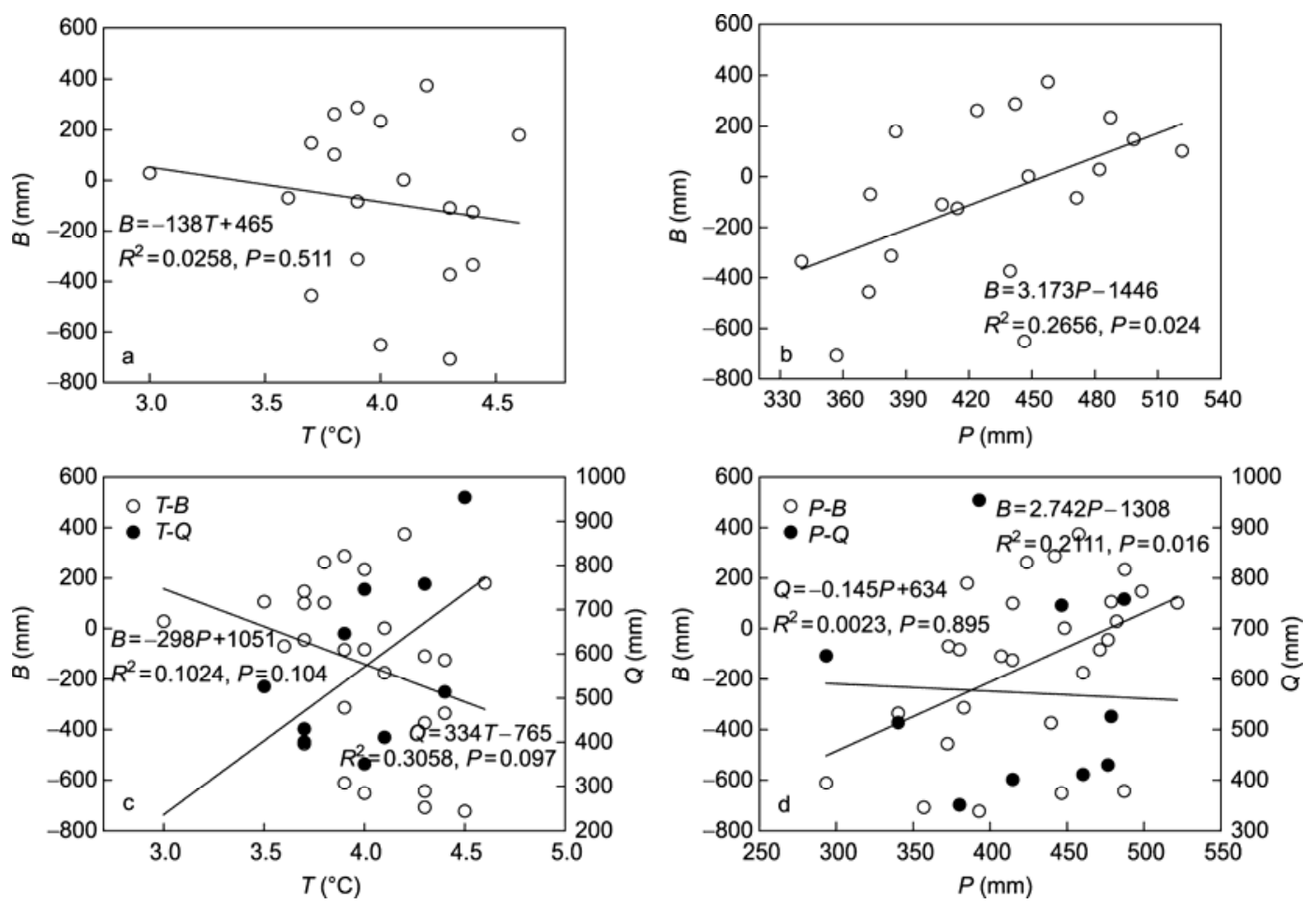

Figure 4 Regression relationships of summer air temperature $(T)$ and annual precipitation $(P)$ vs. annual mass balance $(B)$ and annual discharge $(Q)$ during 1963-1981 $\left(\mathrm{P} 1_{0}\right)(\mathrm{a}, \mathrm{b})$ and 1963-1989 $\left(\mathrm{P} 1_{1}\right)(\mathrm{c}, \mathrm{d})$.

negatively correlated with mass balance and positively with discharge (statistically at 90\%) (Figure 4c), and precipitation is positively correlated with the mass balance (statistically at 98\%) but its relation with discharge is not significant (statistically at $10 \%$ ) (Figure 4d), suggesting that air temperature and precipitation dominate the evolution of glacier zones. However, the effect of precipitation on glacier zones is more significant than the effect of air temperature during $P 1_{1}$, as confirmed by the relations between precipitation $\left(R^{2}=0.21, P=0.02\right)$ and air temperature $\left(R^{2}=0.1\right.$, $P=0.10$ ) and the mass balance (Figure $4 \mathrm{c}, \mathrm{d}$ ). In addition, the relationships, although weak for air temperature vs. mass balance during $\mathrm{P} 1_{0}$, are reasonable because higher air temperature leads to greater glacier melt [42], and the very weak relation for precipitation vs. discharge during $\mathrm{P} 1_{1}$ suggests that glacier-derived discharge is mainly controlled by air temperature rather than precipitation. Therefore, interannual fluctuations in air temperature and particularly precipitation are responsible for changes in glacier zones and snow composition during $\mathrm{P} 1_{0}$ and $\mathrm{P} 1_{1}$.

During $\mathrm{P} 2_{0}$ and $\mathrm{P} 2_{1}$, air temperature is negatively correlated with mass balance and positively with discharge (statistically at 99\%) (Figure 5a,c), and precipitation is positively correlated with discharge (statistically at $91 \%$ for $\mathrm{P} 2_{0}$ and at $82 \%$ for $\mathrm{P} 2{ }_{1}$ ), but the relation between precipitation and mass balance is not significant (statistically at $13 \%$ for $\mathrm{P} 2_{0}$ and at $1 \%$ for $\mathrm{P} 2_{1}$ ) (Figure $5 \mathrm{~b}, \mathrm{~d}$ ). These results suggest that the effect of the air temperature rise is greater than the effect of the precipitation increase, and air temperature overwhelmingly governs the mass balance and discharge and is thus principally responsible for the evolution of both glacier zones and snow composition, as confirmed by the relations between air temperature and the mass balance $\left(R^{2}=\right.$ 0.61 for $\mathrm{P} 2_{0}, P<0.01 ; R^{2}=0.60$ for $\left.\mathrm{P} 2_{1}, P<0.01\right)$ and discharge $\left(R^{2}=0.54\right.$ for $\mathrm{P} 2_{0}, P<0.01 ; R^{2}=0.47$ for $\mathrm{P} 2_{1}, P<$ 0.01 ) (Figure 5a,c). In addition, the extremely weak relationship for precipitation vs. mass balance during $\mathrm{P} 2_{0}$ and $\mathrm{P} 2{ }_{1}$ further indicates that air temperature critically controls the mass balance and hence changes in glacier zones and snow composition. Moreover, the regression results show that a change in air temperature of $1^{\circ} \mathrm{C}$ led to glacier mass losses of $470 \mathrm{~mm}\left(\mathrm{P} 2_{0}\right)$ and $459 \mathrm{~mm}\left(\mathrm{P} 2_{1}\right)$ during a recent period (Figure 5a, c) compared with a loss of $298 \mathrm{~mm}\left(\mathrm{P} 1_{1}\right)$ during an early period over the basin, further implying that the evolutions of both glacier zones and snow composition during recent decades most probably resulted from rapid warming of the climate under global warming. Furthermore, interannual fluctuation in air temperature to some extent was more or less responsible for changes in glacier zones and snow composition during $\mathrm{P} 2_{0}$ and $\mathrm{P} 2_{1}$, but it does not get the run upon potential climate warming under a background of global warming.

\section{Conclusions}

This study analyzed the changes in glacier zones and snow composition of Glacier No. 1 of the Tianshan Mountains 

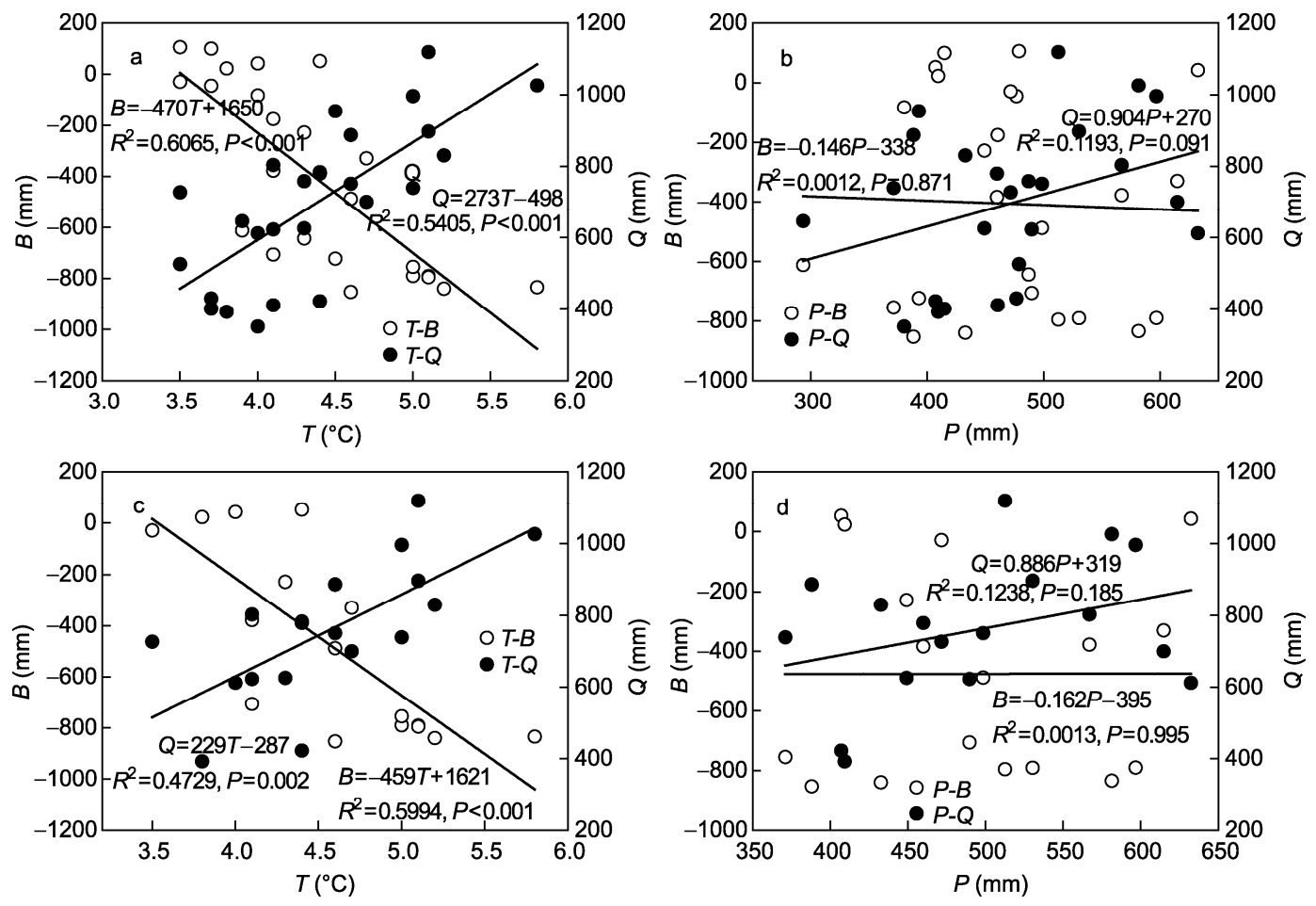

Figure 5 Regression relationships of summer air temperature $(T)$ and annual precipitation $(P)$ vs. annual mass balance $(B)$ and annual discharge $(Q)$ during 1982-2007 (P2 $\left.2_{0}\right)(a, b)$ and 1990-2007 (P2 1$)(c, d)$.

since 1961, and their possible relations with climate change. During $\mathrm{P} 1_{0}$ (1963-1981) and $\mathrm{P} 1_{1}$ (1963-1989), precipitation dominated snow composition, and air temperature and precipitation controlled glacier zones, but interannual change in precipitation had a relatively large effect on glacier zones and snow composition. During $\mathrm{P} 22_{0}(1982-2007)$ and $\mathrm{P} 22_{1}$ (1990-2007), the effect of the air temperature rise $\left(0.57^{\circ} \mathrm{C} / 10 \mathrm{a}\right.$ for $\mathrm{P} 2_{0}, 0.76^{\circ} \mathrm{C} / 10$ a for $\mathrm{P} 2_{1}$ ) overcame that of the precipitation increase $\left(51.3 \mathrm{~mm} / 10\right.$ a for $\left.\mathrm{P} 2_{0}\right)$, and air temperature was principally responsible for the evolution of glacier zones and snow composition. Moreover, a temperature change of $1^{\circ} \mathrm{C}$ led to glacier mass losses of $470 \mathrm{~mm}\left(\mathrm{P} 2_{0}\right)$ and $459 \mathrm{~mm}\left(\mathrm{P} 2_{1}\right)$ compared with a loss of $298 \mathrm{~mm}$ in $\mathrm{P} 1_{1}$, further implying that the evolution of glacier zones and snow composition most probably resulted from recent climate warming rather than interannual fluctuation in air temperature.

We would like to thank all anonymous reviewers for their constructive suggestions. This work was supported by the National Natural Science Foundation of China (40871036), the Open Foundation of the State Key Laboratory of Cryospheric Science, Chinese Academy of Sciences (SKLCSO904), the China Postdoctoral Science Foundation (20110490062) and the National Natural Science Foundation of China (41001006).

1 Oerlemans J. Glaciers as indicators of a carbon dioxide warming. Nature, 1986, 320: 607-609

2 Oerlemans J, Fortuin J P F. Sensitivity of glaciers and small ice caps to greenhouse warming. Science, 1992, 258: 115-117

3 Fischer A. Glaciers and climate change: Interpretation of 50 years of direct mass balance of Hintereisferner. Glob Planet Change, 2010, 71: 13-26

4 Oerlemans J. Quantifying global warming from the retreat of glaciers. Science, 1994, 264: 243-245

5 Benson C S. Stratigraphic studies in the snow and firn of the Greenland ice sheet. Res. Rep. 70, reprint, U.S. Army Corps of Engineers Snow Ice and Permafrost Res. Estab., Corps of Engineers, Hanover, N. H., 1962

6 Shumskii P A. Principles of Structural Glaciology. New York: Dover Press, 1964

7 Paterson W S B. The Physics of Glaciers (3rd ed.). Oxford: Pergamon Press, 1994

8 Partington K C. Discrimination of glacier facies using multi-temporal SAR data. J Glaciol, 1998, 44: 42-53

9 Rau F, Braun M, Saurer H, et al. Monitoring multi-year snow cover dynamics on the Antarctic Peninsula. Polarforschung, 2000, 67: 27-40

10 Rau F, Braun M, Friedrich M, et al. Radar glacier zones and their boundaries as indicators of glacier mass balance and climatic variability. In: Proceedings of EARSeL-SIG-Workshop Land Ice and Snow. Dresden/FRG, 2000. 317-327

11 Wang N L, He J Q, Pu J C, et al. Variations in equilibrium line altitude of the Qiyi Glacier, Qilian Mountains, over the past 50 years. Chinese Sci Bull, 2010, 55: 3107-3115

12 Yao T D, Li Z G, Yang W, et al. Glacial distribution and mass balance in the Yarlung Zangbo River and its influence on lakes. Chinese Sci Bull, 2010, 55: 1750-1756

13 Christine P, Martin S. Stratigraphy and changes in hardness of snow measured by hand, ramsonde and snow micro penetrometer: A comparison with planar sections. Cold Reg Sci Technol, 2003, 37: 393-405

14 Sturm M, Johnson J B. Natural convection in sub arctic snow cover. J Geophys Res, 1991, 96: 11657-11671

15 Arons E M, Colbeck S C. Geometry of heat and mass transfer in dry snow: A review of theory and experiment. Rev Geophys, 1995, 33: $463-493$ 
16 Grenfell T C, Warren S G, Mullen P C. Reflection of solar radiation by the Antarctic snow surface at ultraviolet, visible, and near-infrared wave lengths. J Geophys Res, 1994, 99: 18669-18684

17 Li X Q, Qin D H, Jiang G B, et al. Atmospheric pollution of a remote area of Tianshan Mountain: Ice core record. J Geophys Res, 2003, 108: 4406-4416

18 Luo H Z. Hydrochemical features of the Glacier No.1 in the source region of Urumqi River, Tianshan (in Chinese). J Glaciol Geocryol, 1983, 5: 55-64

19 Williams M, Tonnessen K, Melack J, et al. Sources and spatial variation of the chemical composition of snow in the Tianshan, China. Ann Glaciol, 1992, 16: 25-32

20 Zhang Y S, Kang E S, Liu C H. Mountain climate analysis in Urumqi River valley, Tianshan (in Chinese). J Glaciol Geocryol, 1994, 16: 333-341

21 Li X Y, Li Z Q, Ding Y J, et al. Seasonal variations of pH and electrical conductivity of a snow-firn snow pack on the Glacier No.1 at the headwaters of Urumqi River, eastern Tianshan Mountains, China. Cold Reg Sci Technol, 2007, 48: 55-63

22 Ye B S, Yang D Q, Jiao K Q, et al. The Urumqi River source Glacier No.1, Tianshan Mountains, China: Changes over the past 45 years. Geophys Res Lett, 2005, 32, doi:10.1029/2005GL024178

23 Yang H A, Li Z Q, Wang F T. Mass balance of the Glacier No.1 at the headwaters of Uqumqi River, Tianshan Mountains (in Chinese). Annu Rep Tianshan Glaciol Station, 2009, 18: 1-17

24 Han T D, Ding Y J, Ye B S, et al. Mass-balance characteristics of Urumqi Glacier No.1, Tianshan Mountains, China. Ann Glaciol, 2006, 43: $323-328$

25 Jing Z F, Jiao K Q, Yao T D, et al. Mass balance and recession of Urumqi Glacier No.1, Tianshan Mountains, China, over the last 45 years. Ann Glaciol, 2006, 43: 214-217

26 Xie Z C, Huang M H, Mi A L. An Evolution of the Snow-firn Layer and Ice Formation Process on Glacier No.1 at the Urumqi River head, Tianshan Mountains, in the Glaciology and Hydrology at the Headwaters of Urumqi River, Tianshan Mountains (in Chinese). Beijing: Science Press, 1965. 1-13

27 Wang X J, Zhang J H. Observation on snow stratigraphy and glaciers accumulation in accumulation area on the Glacier No.1, at the Urumqi River head, Tianshan Mountains, China (in Chinese). Annu Rep Tianshan Glaciol Station, 1981, 1: 11-21

28 Li X Y, Li Z Q, You X N, et al. Glacier zones and stratigraphy pro- files of snow pits on the Glacier No.1 at the headwaters of Urumqi River (in Chinese). J Glaciol Geocryol, 2006, 27: 37-44

29 Liu C H, Дюргеров M B. Processes of mass balance of the Glacier No.1 at the headwaters of Urumqi River, Tianshan Mountains (in Chinese). Annual Report of Tianshan Glaciological Station, 1989, 8: $1-23$

30 Li X Y, Ding Y J, Liu S Y, et al. Further study of ice formation zones on the Glacier No.1 at the Urumqi River headwaters, Tianshan Mountains (in Chinese). J Glaciol Geocryol, 2008, 30: 93-99

31 Wang F T, Li Z Q, Edwards R, et al. Long-term changes in the snow-firn snow pack stratigraphy on Urumqi Glaciers No. 1, eastern Tianshan Mountains, China. Ann Glaciol, 2007, 46: 331-334

32 Li Z Q, Li X Y. Annual Reports of Tianshan Glaciological Station (in Chinese). Lanzhou: Zhongke Press, 2006. 230-240

33 Colbeck S. The International Classification for Seasonal Snow on the Ground. The International Commission on Snow and Ice of the International Association of Scientific Hydrology and IGS, 1990

$34 \mathrm{Li} \mathrm{Z} \mathrm{Q.} \mathrm{A} \mathrm{glacier} \mathrm{meltwater} \mathrm{pool} \mathrm{was} \mathrm{discovered} \mathrm{at} \mathrm{summit} \mathrm{of} \mathrm{east}$ branch of Glacier No.1 at Urumqi River Head, Tianshan Mts., Xinjiang (in Chinese). J Glaciol Geocryol, 2005, 27: 150-152

35 Anthony J C. On the accumulation and seasonal stratification of snow at the south pole. J Glaciol, 1964, 5: 467-477

36 Wang F T, Li Z Q, You X N, et al. Seasonal evolution of aerosol stratigraphy in Glacier No. 1 percolation zone, eastern Tianshan, China. Ann Glaciol, 2006, 43: 245-249

37 Zhang X S, Zhu G C, Qian S L, et al. Radar measuring ice thickness of the Glacier No. 1 at the source of Urumqi River, Tianshan Mountains (in Chinese). J Glaciol Geocryol, 1985, 7: 153-162

38 Vincent C, Kappenberger G, Vall F, et al. Ice ablation as evidence of climate change in the Alps over the 20th century. J Geophys Res, 2003, 109, doi:10.1029/2003JD003857

39 McCabe G J, Fountain A G. Relations between atmospheric circulation and mass balance of South Cascade Glacier, Washington, USA. Arc Alp Res, 1995, 27: 226-233

40 Hodge S M, Trabant D C, Krummel R M, et al. Climate variations and changes in mass of three glaciers in western North America. J Clim, 1998, 11: 2161-2179

41 Dyurgerov M B, Meier M F. Twentieth century climate change: Evidence from small glaciers. Proc Natl Acad Sci USA, 2000, 97: 1406-1411

42 Liu C H, Xie Z C, Dyurgerov M B. Tianshan Glacier (in Chinese). Beijing: Science Press, 1998. 227

Open Access This article is distributed under the terms of the Creative Commons Attribution License which permits any use, distribution, and reproduction in any medium, provided the original author(s) and source are credited. 